\title{
Kinetics and mechanism of oxidation of L-leucine by alkaline diperiodatocuprate(III) - A free radical intervention, deamination and decarboxylation
}

\author{
KEERTI M NAIK and SHARANAPPA T NANDIBEWOOR* \\ Post Graduate Department of Studies in Chemistry, Karnatak University, Dharwad 580003, India \\ e-mail: stnandibewoor@yahoo.com
}

MS received 29 November 2011; revised 5 January 2012; accepted 16 January 2012

\begin{abstract}
The kinetics of oxidation of L-leucine by diperiodatocuprate (III) (DPC) in aqueous alkaline medium at a constant ionic strength of $0.10 \mathrm{~mol} \mathrm{dm}^{-3}$ was studied spectrophotometrically. The reaction between L-leucine and DPC in alkaline medium exhibits 1:4 stoichiometry (L-leucine: DPC). The reaction is of first order in [DPC] and has less than unit order in both [L-leucine] and [alkali]. However, the order in [Lleucine] and [alkali] changes from first order to zero order as their concentration increase. Intervention of free radicals was observed in the reaction. Increase in periodate concentration decreased the rate. The oxidation reaction in alkaline medium has been shown to proceed via a monoperiodatocuprate (III) - L-leucine complex, which decomposed slowly in a rate-determining step followed by other fast steps to give the products. The main oxidative products were identified by spot test and GC-MS. The reaction constants involved in the different steps of the mechanism were calculated.
\end{abstract}

Keywords. L-leucine; diperiodatocuprate (III); oxidation; kinetics; mechanism.

\section{Introduction}

Amino acids not only act as the building blocks in protein synthesis, but they also play a significant role in metabolism. Amino acids can undergo many types of reaction depending on whether a particular amino acid contains nonpolar groups or polar substituents. The oxidation of amino acids is of interest as the oxidation products differ for different oxidants. ${ }^{1}$ Thus, the study of amino acids becomes important because of their biological significance and selectivity toward the oxidant. L-leucine is an essential amino acid. It forms active sites of enzymes and helps in maintaining their proper conformation by keeping them in proper ionic states. So, oxidation of L-leucine may help in understanding some aspects of enzyme kinetics. Recent research has discovered that L-leucine acts in a unique way: it can help burn fat without burning muscle.

In recent years, the study of the highest oxidation state of transition metals has intrigued many researchers. Transition metals in a higher oxidation state can be stabilized by chelation with suitable

*For correspondence polydentate ligands. Metal chelates such as diperiodatocuprate(III), ${ }^{2}$ diperiodatoargentate(III),${ }^{3}$ and diperiodatonickelate(IV) ${ }^{4}$ are good oxidants in a medium with an appropriate $\mathrm{pH}$ value. Copper (III) is shown to be an intermediate in the copper(II)-catalysed oxidation of amino acids by peroxydisulfate. ${ }^{5}$ The oxidation reaction usually involves the copper(II) - copper(I) couple, and such aspects are detailed in different reviews. ${ }^{6}$ The use of diperiodatocuprate(III) (DPC) as an oxidant in alkaline medium is new and restricted to a few cases because of its limited solubility and stability in aqueous medium. Copper complexes have occupied a major place in oxidation chemistry because of their abundance and relevance in biological chemistry. ${ }^{7} \mathrm{Cop}-$ per (III) is involved in many biological electron transfer reactions. ${ }^{8}$ When the copper (III) periodate complex is oxidant and multiple equilibria between different copper (III) species ${ }^{9}$ are involved, it would be interesting to know which of the species is the active oxidant.

The kinetics of oxidation of L-leucine by DPC has not been reported in the literature. In view of the medicinal value and potential pharmaceutical importance of L-leucine and lack of literature on the oxidation mechanism of this drug by DPC, there was a need for understanding the oxidation mechanism of this bioactive 
compound. Hence the title reaction was investigated in detail.

\section{Experimental}

\subsection{Materials and methods}

All chemicals used were of reagent grade, and doubly distilled water was used throughout the work. A solution of L-leucine was prepared by dissolving an appropriate amount of L-leucine (S. D. Fine Chemicals) in doubly distilled water. The required concentration of L-leucine was prepared from its stock solution. The copper (III) periodate complex was prepared by standard procedure. ${ }^{10}$ Existence of copper (III) complex was verified by its UV-vis spectrum, which showed an absorption band with maximum absorption at $415 \mathrm{~nm}$. The aqueous solution of copper (III) was standardized by iodometric titration and gravimetrically by the thiocyanate ${ }^{11}$ method. The copper (II) solution was prepared by dissolving the known amount of copper sulfate $(\mathrm{BDH})$ in distilled water. Periodate solution was prepared by weighing the required amount of sample in hot water and used after keeping it for $24 \mathrm{~h}$. Its concentration was ascertained iodometrically ${ }^{12}$ at neutral $\mathrm{pH}$ by phosphate buffer. $\mathrm{KOH}$ and $\mathrm{KNO}_{3}$ (BDH, AR) were employed to maintain the required alkalinity and ionic strength, respectively, in reaction solutions.

\subsection{Instruments used}

(i) For kinetic measurements, a Peltier Accessory (temperature control) attached Varian CARY 50 Bio UV-vis Spectrophotometer (Varian, Victoria-3170, Australia) was used. (ii) For product analysis, a QP-2010S Shimadzu gas chromatograph mass spectrometer, Nicolet 5700-FT-IR spectrometer (Thermo, U.S.A.) and for $\mathrm{pH}$ measurements, an Elico $\mathrm{pH}$ meter model LI120 were used.

\subsection{Kinetic measurements}

The kinetic measurments were performed on a Peltier Accessory (temperature control) attached Varian CARY 50 Bio UV-vis Spectrophotometer (Varian, Victoria3170, Australia). The kinetics was followed under pseudo first-order condition, where [L-leucine] $>[\mathrm{DPC}]$ at $25 \pm 0.1^{\circ} \mathrm{C}$, unless specified. The reaction was initiated by mixing the DPC with L-leucine solution, which also contained the required concentration of $\mathrm{KNO}_{3}$,
$\mathrm{KOH}$, and $\mathrm{KIO}_{4}$. The progress of the reaction was followed spectrophotometrically at $415 \mathrm{~nm}$ by monitoring the decrease in absorbance due to DPC with the molar absorbancy index, $\varepsilon$ to be $6230 \pm 100 \mathrm{dm}^{3} \mathrm{~mol}^{-1} \mathrm{~cm}^{-1}$. It was verified that there is a negligible interference from other species present in the reaction mixture at this wavelength.

The pseudo first-order rate constants, $\mathrm{k}_{\mathrm{obs}}$, were determined from the log (absorbance) versus time plots and were the average of duplicate runs (table 1). The plots were linear up to $80 \%$ completion of reaction under the range of $\left[\mathrm{OH}^{-}\right]$used and the rate constants were reproducible to within $\pm 5 \%$. The orders for various species were determined from the slopes of plots of $\log k_{\mathrm{obs}}$ versus $\log$ respective concentration of species except for [DPC] in which no variation of $k_{\mathrm{obs}}$ was observed as expected to the reaction condition. During the kinetics, a constant concentration viz. $1.0 \times 10^{-5}$ mol dm ${ }^{-3}$ of $\mathrm{KIO}_{4}$ was used throughout the study unless otherwise stated. Since periodate is present in excess in DPC, the possibility of oxidation of L-leucine by periodate in alkaline medium at $25^{\circ} \mathrm{C}$ was tested. The progress of the reaction was followed iodometrically. However, it was found that there was no significant reaction under the experimental conditions employed compared to the DPC oxidation of L-leucine. The total concentrations of periodate and $\mathrm{OH}^{-}$was calculated by considering the amount present in the DPC solution and that additionally added. Kinetic runs were also carried out in $\mathrm{N}_{2}$ atmosphere in order to understand the effect of dissolved oxygen on the rate of reaction. No significant difference in the results was obtained under a $\mathrm{N}_{2}$ atmosphere and in the presence of air. In view of the ubiquitous contamination of carbonate in the basic medium, the effect of carbonate was also studied. Added carbonate had no effect on the reaction rates. The spectral changes during the reaction are shown in figure 1. It is evident from the figure that the concentration of DPC decreases by observing the absorbance at $415 \mathrm{~nm}$.

Regression analysis of experimental data to obtain the regression coefficient $r$ and standard deviation $S$ of points from the regression line was performed using Microsoft 2003 Excel program.

\subsection{Stoichiometry and product analysis}

Different sets of reaction mixtures containing various ratios of DPC to L-leucine in the presence of constant amounts of $\mathrm{OH}^{-}$and $\mathrm{KNO}_{3}$ were kept for $6 \mathrm{~h}$ in a closed vessel under nitrogen atmosphere. The remaining concentration of DPC was estimated by spectrophotomet- 
Table 1. Effect of [DPC], [L-leucine], $\left[\mathrm{IO}_{4}^{-}\right]$and $\left[\mathrm{OH}^{-}\right]$on the oxidation of L-leucine by diperiodatocuprate(III) in alkaline medium at $25^{\circ} \mathrm{C}, \mathrm{I}=0.1 \mathrm{~mol} \mathrm{dm}^{-3}$.

\begin{tabular}{lccccc}
\hline $\begin{array}{l}{[\mathrm{DPC}] \times 10^{5}} \\
\left(\mathrm{~mol} \mathrm{dm}^{-3}\right)\end{array}$ & $\begin{array}{c}\text { L-leucine }] \times 10^{3} \\
\left(\mathrm{~mol} \mathrm{dm}^{-3}\right)\end{array}$ & $\begin{array}{c}{\left[\mathrm{IO}_{4}^{-}\right] \times 10^{5}} \\
\left(\mathrm{~mol} \mathrm{dm}^{-3}\right)\end{array}$ & $\begin{array}{c}{\left[\mathrm{OH}^{-}\right]} \\
\left(\mathrm{mol} \mathrm{dm}^{-3}\right)\end{array}$ & $\begin{array}{c}\mathrm{k}_{\mathrm{obs}} \times 10^{3} \\
\left(\mathrm{~s}^{-1}\right)\end{array}$ & $\begin{array}{c}\mathrm{k}_{\mathrm{cal}} \times 10^{3} \\
\left(\mathrm{~s}^{-1}\right)\end{array}$ \\
\hline 1.0 & 3.0 & 1.0 & 0.05 & 3.01 & 2.89 \\
3.0 & 3.0 & 1.0 & 0.05 & 2.77 & 2.89 \\
5.0 & 3.0 & 1.0 & 0.05 & 2.79 & 2.89 \\
8.0 & 3.0 & 1.0 & 0.05 & 2.98 & 2.89 \\
10.0 & 3.0 & 1.0 & 0.05 & 2.85 & 2.89 \\
5.0 & 1.0 & 1.0 & 0.05 & 2.00 & 2.00 \\
5.0 & 3.0 & 1.0 & 0.05 & 2.79 & 2.89 \\
5.0 & 5.0 & 1.0 & 0.05 & 3.14 & 3.16 \\
5.0 & 8.0 & 1.0 & 0.05 & 3.34 & 3.34 \\
5.0 & 10.0 & 1.0 & 0.05 & 3.51 & 3.41 \\
5.0 & 3.0 & 1.0 & 0.05 & 2.79 & 2.89 \\
5.0 & 3.0 & 3.0 & 0.05 & 2.11 & 2.13 \\
5.0 & 3.0 & 5.0 & 0.05 & 1.68 & 1.69 \\
5.0 & 3.0 & 8.0 & 0.05 & 1.28 & 1.29 \\
5.0 & 3.0 & 10.0 & 0.05 & 1.07 & 1.11 \\
5.0 & 3.0 & 1.0 & 0.01 & 1.76 & 1.73 \\
5.0 & 3.0 & 1.0 & 0.02 & 2.20 & 2.13 \\
5.0 & 3.0 & 1.0 & 0.05 & 2.79 & 2.89 \\
5.0 & 3.0 & 1.0 & 0.08 & 3.13 & 3.08 \\
5.0 & 3.0 & 1.0 & 0.1 & 3.34 & 3.15 \\
\hline
\end{tabular}

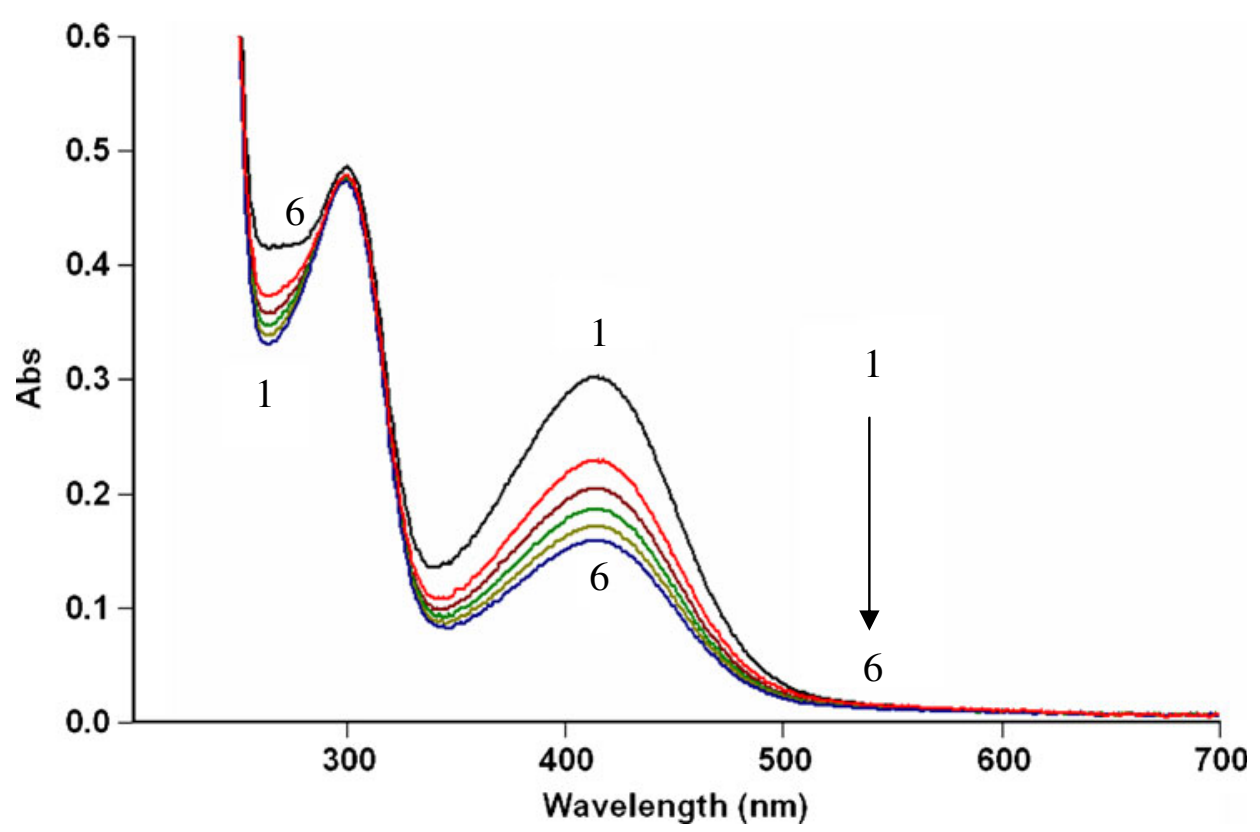

Figure 1. UV-vis spectra changes during the oxidation of L-leucine by alkaline diperiodatocuprate(III) at $298 \mathrm{~K},[\mathrm{DPC}]=5.0 \times 10^{-5}$, [L-leucine $]=3.0 \times 10^{-3},\left[\mathrm{OH}^{-}\right]=$ 0.05 and $\mathrm{I}=0.1 \mathrm{~mol} \mathrm{dm}^{-3}$ with scanning time of (1) $0.5 \mathrm{~min}$, (2) $1.0 \mathrm{~min}$. (3) $1.5 \mathrm{~min}$, (4) $2.0 \mathrm{~min}$, (5) $2.5 \mathrm{~min}$ and (6) $3.0 \mathrm{~min}$. 
rically. The results indicated 1:4 stoichiometry as given in Eq. (1).

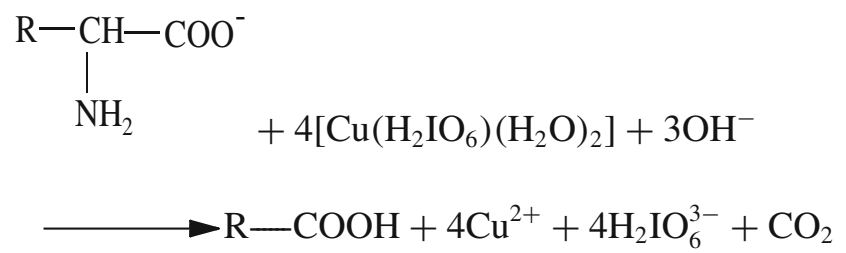

$+\mathrm{NH}_{3}+9 \mathrm{H}_{2} \mathrm{O}$<smiles>[R]CC(C)C</smiles>

The reaction product was extracted with ether and recrystallised from aqueous alcohol. Only one product was obtained as evidenced by a single spot on thin layer chromatography, which was identified as 3-methyl butanoic acid by spot test ${ }^{13}$ and was characterized by GC-MS spectral studies.

GC-MS data was obtained on a QP-2010S Shimadzu gas chromatograph mass spectrometer. The mass spectral data showed a molecular ion peak at $102 \mathrm{~m} / \mathrm{z}$ confirming the presence of 3-methyl butanoic acid (figure 2 ). The by-product, ammonia was detected by Nessler's reagent, and the product $\mathrm{CO}_{2}$ was qualitatively detected by bubbling $\mathrm{N}_{2}$ gas through the acidified reaction mixture and passing the liberated gas through tube containing limewater. Another product, $\mathrm{Cu}$ (II) was identified by UV-vis spectra. The reaction products do not undergo further oxidation under the present kinetic conditions.

\section{Results}

\subsection{Reaction orders}

The reaction orders were determined from the slope of $\log k_{\text {obs }}$ versus $\log$ (concentration) plots by varying the concentrations of L-leucine, alkali, and periodate in turn, while keeping all other concentrations and conditions constant, except for DPC concentration.

\subsection{Effect of DPC}

The oxidant, DPC concentration was varied in the range $1.0 \times 10^{-5}$ to $1.0 \times 10^{-4} \mathrm{~mol} \mathrm{dm}^{-3}$, and the fairly constant $k_{\text {obs }}$ values indicate that order with respect to [DPC] was unity (table 1). This was also confirmed by linearity of the plots of log [absorbance] versus time ( $r \geq 0.9711, S \leq 0.013$ ) up to $80 \%$ completion of the reaction.

\subsection{Effect of L-leucine}

The effect of [L-leucine] on the rate of reaction was studied at constant concentrations of alkali, DPC, and periodate at a constant ionic strength of $0.1 \mathrm{~mol} \mathrm{dm}^{-3}$. The substrate L-leucine was varied in the range $1.0 \times$ $10^{-3}$ to $1.0 \times 10^{-2} \mathrm{~mol} \mathrm{dm}^{-3}$. The $\mathrm{k}_{\mathrm{obs}}$ values increased with increase in concentration of L-leucine. The order with respect to [L-leucine] was found to be less than unity (table 1) $(r \geq 0.9933, S \leq 0.005)$ under the experimental concentrations. The order in [L-leucine] changes from first order to zero order as [L-leucine] increases (figure 3).

\subsection{Effect of alkali}

The effect of increase in concentration of alkali on the reaction was studied at constant concentrations of

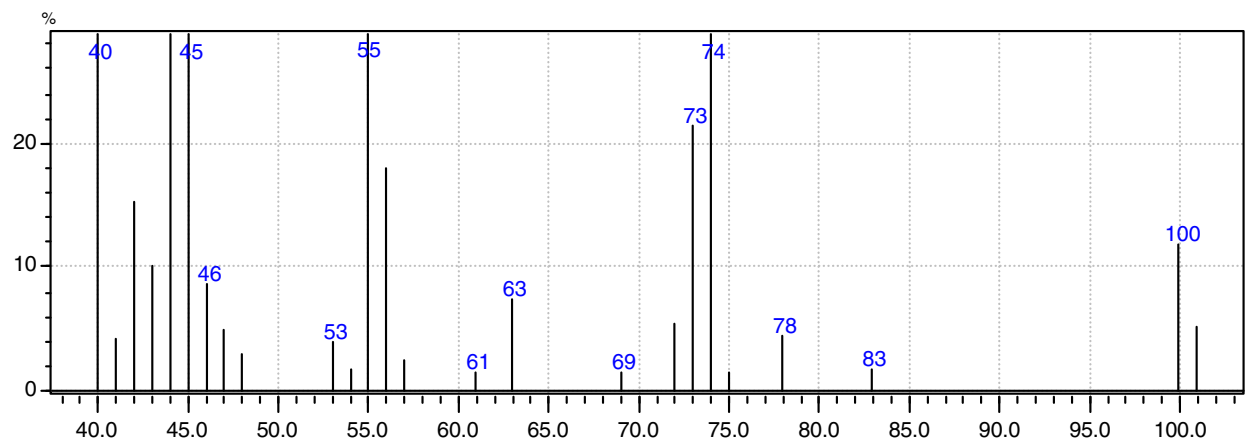

Figure 2. Mass spectrum of reaction product, 3-methyl butanoic acid with its molecular ion peak at $102 \mathrm{~m} / \mathrm{z}$. 


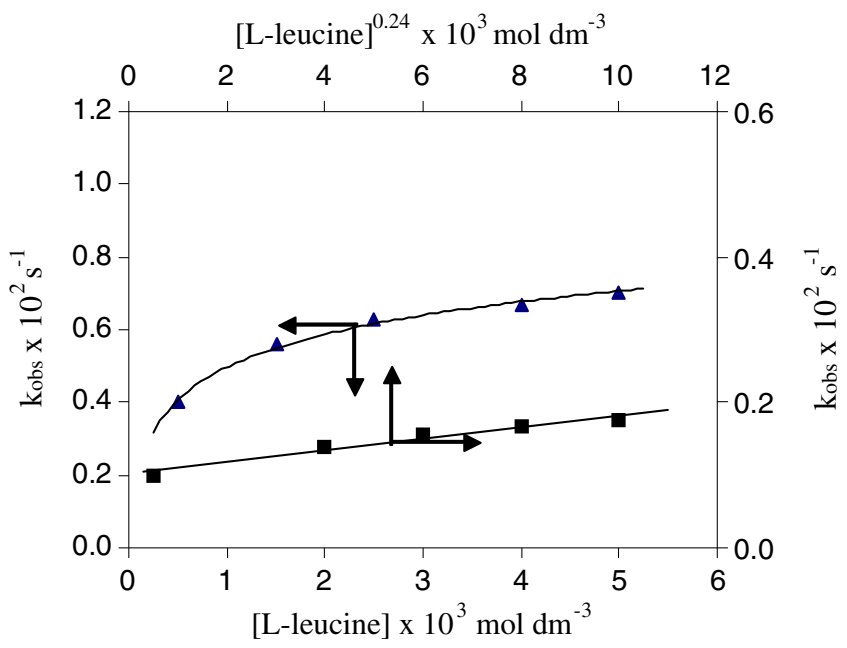

Figure 3. Plots of $\mathrm{k}_{\mathrm{obs}}$ vs. [L-leucine] ${ }^{0.24}$ and $\mathrm{k}_{\mathrm{obs}}$ vs. [Lleucine] (from table 1).

L-leucine, DPC, and periodate at a constant ionic strength of $0.1 \mathrm{~mol} \mathrm{dm}^{-3}$ at $25^{\circ} \mathrm{C}$. The rate constants increased with increase in alkali concentration (table 1), indicating apparent less than unit order dependence of rate on alkali concentration $(\mathrm{r} \geq 0.9780, \mathrm{~S} \leq$ 0.006). Similar to the case of L-leucine, the order in alkali changes from first order to zero order as $\left[\mathrm{OH}^{-}\right]$ increases.

\subsection{Effect of Periodate}

The effect of increasing concentration of periodate was studied by varying the periodate concentration from $1.0 \times 10^{-5}$ to $1.0 \times 10^{-4} \mathrm{~mol} \mathrm{dm}^{-3}$ keeping all other reactants concentrations constant. It was found that the added periodate had a retarding effect on the rate of reaction, the order with respect to periodate concentration being negative less than unity (table 1).

\subsection{Effect of ionic strength (I) and dielectric constant of the medium $(D)$}

Ionic strength was varied by the addition of $\mathrm{KNO}_{3}$ at constant [DPC], [L-leucine], $\left[\mathrm{OH}^{-}\right]$, and $\left[\mathrm{IO}_{4}^{-}\right]$. It was found that increasing ionic strength had no significant effect on the rate of the reaction thereby indicating that the reaction is insensitive to ionic strength.

Dielectric constant of the medium, D, was varied by varying $t$-butyl alcohol and water percentage (1$5 \%$ ). The $\mathrm{D}$ values were calculated from the equation $D=\mathrm{D}_{\mathrm{w}} \mathrm{V}_{\mathrm{w}}+\mathrm{D}_{\mathrm{B}} \mathrm{V}_{\mathrm{B}}$, where $\mathrm{D}_{\mathrm{w}}$ and $\mathrm{D}_{\mathrm{B}}$ are dielectric constants of pure water and $t$-butyl alcohol, respectively, and $\mathrm{V}_{\mathrm{w}}$ and $\mathrm{V}_{\mathrm{B}}$ are the volume fractions of components water and $t$-butyl alcohol, respectively, in the total mixture. The $t-\mathrm{BuOH}$ was not oxidized under the experimental conditions. There was no effect of dielectric constant on the rate of reaction.

Thus from the observed experimental results, the rate law for reaction is given as follows:

Rate $=\mathrm{k}_{\mathrm{obs}}[\mathrm{L}-\text { leucine }]^{0.24}[\mathrm{DPC}]^{1.0}\left[\mathrm{OH}^{-}\right]^{0.27}\left[\mathrm{IO}_{4}^{-}\right]^{-0.40}$.

\subsection{Effect of added products}

The externally added products, 3-methyl butanoic acid and copper (II) $\left(\mathrm{CuSO}_{4}\right)$ in the range $1.0 \times 10^{-4}$ to 1.0 $\times 10^{-3} \mathrm{~mol} \mathrm{dm}^{-3}$ did not have any significant effect on the rate of the reaction.

\subsection{Polymerization study (test for free radicals)}

DPC is a one equivalent oxidant. Hence, intervention of a free radical, generated from the organic compound, was expected. The possibility of intervention of free radicals was detected as follows. The reaction mixture, to which a known quantity of acrylonitrile (scavenger) had been added initially, was kept in an inert atmosphere for two hours. On diluting the reaction mixture with methanol, a white precipitate was formed, indicating the intervention of free radicals in the reaction. The blank experiments of either DPC or L-leucine alone with acrylonitrile did not induce any polymerization under the same condition as those induced for reaction mixture. Initially, added acrylonitrile decreases the rate of reaction indicating free radical intervention, which is the case in earlier work. ${ }^{14}$ The rate constant obtained in the absence of acrylonitrile was found to be $2.79 \times 10^{-3} \mathrm{~s}^{-1}$, whereas this value decreased to $1.67 \times 10^{-3} \mathrm{~s}^{-1}$ in the presence of acrylonitrile $\left(1 \times 10^{-4} \mathrm{M}\right)$.

\subsection{Effect of temperature}

The rate of reaction was measured at four different temperatures under standard condition. The rate constant of the slow step (k) of scheme 1 were obtained from the slopes and intercepts of $1 / \mathrm{k}_{\mathrm{obs}}$ versus $1 /$ [ $\mathrm{L}$-leucine], $1 / \mathrm{k}_{\text {obs }}$ versus $\left[\mathrm{H}_{3} \mathrm{IO}_{6}^{2-}\right]$, and $1 / \mathrm{k}_{\mathrm{obs}}$ versus $1 /\left[\mathrm{OH}^{-}\right]$plots at four different temperatures. The data are subjected into least square analysis which is given in tables $2 \mathrm{a}$ and $2 \mathrm{~b}$. From the plot of $\log \mathrm{k}$ vs $1 / \mathrm{T}, \mathrm{E}_{\mathrm{a}}$ was obtained and other activation parameters have also been calculated and tabulated in tables $2 \mathrm{a}$ and $2 \mathrm{~b}$. 


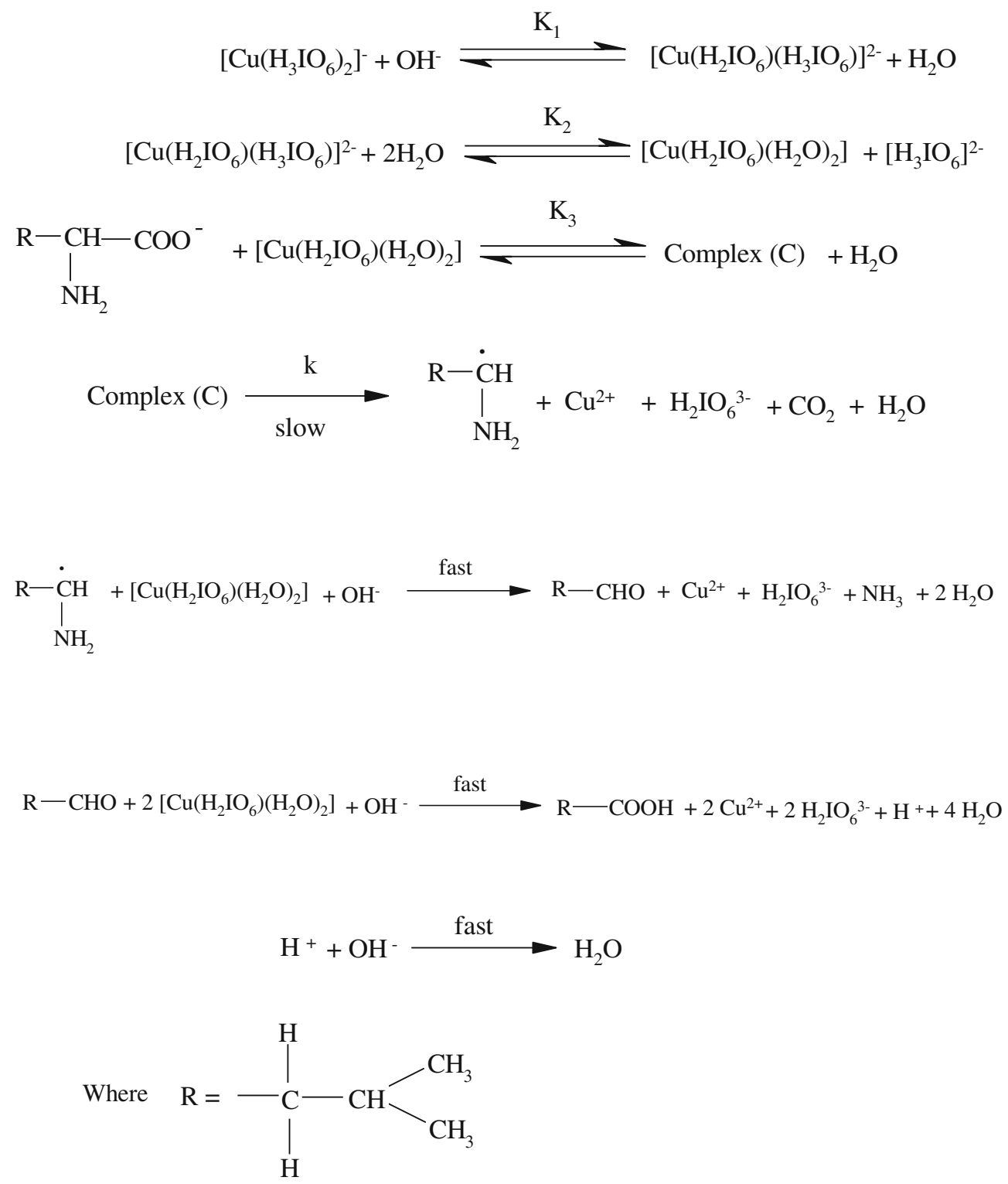

Scheme 1. Detailed mechanistic pathways for the oxidation of L-leucine by alkaline diperiodatocuprate (III).

\section{Discussion}

The water-soluble copper (III) periodate complex is reported ${ }^{15}$ to be $\left[\mathrm{Cu}\left(\mathrm{HIO}_{6}\right)_{2}\right]^{5-}$. However, in an

Table 2a. Effect of temperature on $\mathrm{k}$ for the oxidation of L-leucine by diperiodatocuprate(III) in aqueous alkaline medium.

\begin{tabular}{lc}
\hline Temperature (K) & $\mathrm{k} \times 10^{3} \mathrm{~s}^{-1}$ \\
\hline 288 & 1.42 \\
298 & 3.70 \\
303 & 7.29 \\
308 & 10.29 \\
\hline
\end{tabular}

aqueous alkaline medium and at a high $\mathrm{pH}$ range as employed in the study, periodate is unlikely to exist as $\mathrm{HIO}_{6}^{4-}$ (as present in the complex) as is evident from its involvement in the multiple

Table 2b. Activation parameters for the oxidation of Lleucine by diperiodatocuprate (III) in aqueous alkaline medium.

\begin{tabular}{lc}
\hline Parameters & Values \\
\hline $\mathrm{Ea}\left(\mathrm{k} \mathrm{J} \mathrm{mol}{ }^{-1}\right)$ & $75 \pm 3$ \\
$\Delta \mathrm{H}^{\#}\left(\mathrm{k} \mathrm{J} \mathrm{mol}^{-1}\right)$ & $72 \pm 4$ \\
$\Delta \mathrm{S}^{\#}\left(\mathrm{~J} \mathrm{~K}^{-1} \mathrm{~mol}^{-1}\right)$ & $-49 \pm 3$ \\
$\Delta \mathrm{G}_{298 K}^{\#}\left(\mathrm{k} \mathrm{J} \mathrm{mol}^{-1}\right)$ & $87 \pm 1$ \\
$\log \mathrm{A}$ & $10.6 \pm 1.0$
\end{tabular}


equilibria $^{16}((2)-(4))$ depending on the $\mathrm{pH}$ of the solution.

$$
\begin{aligned}
& \mathrm{H}_{5} \mathrm{IO}_{6} \rightleftharpoons \mathrm{H}_{4} \mathrm{IO}_{6}^{-}+\mathrm{H}^{+} \\
& \mathrm{K}_{1}^{\prime}=5.1 \times 10^{-4} \\
& \mathrm{H}_{4} \mathrm{IO}_{6}^{-}=\mathrm{H}_{3} \mathrm{IO}_{6}^{2-}+\mathrm{H}^{+} \\
& \mathrm{K}_{2}^{\prime}=4.9 \times 10^{-9} \\
& \mathrm{H}_{3} \mathrm{IO}_{6}^{2-} \rightleftharpoons \mathrm{H}_{2} \mathrm{IO}_{6}^{3-}+\mathrm{H}^{+} \\
& \mathrm{K}_{3}^{\prime}=2.5 \times 10^{-12} .
\end{aligned}
$$

Periodic acid exists in acid medium as $\mathrm{H}_{5} \mathrm{IO}_{6}$ and as $\mathrm{H}_{4} \mathrm{IO}_{6}^{-}$around $\mathrm{pH}$ 7. Thus, under the conditions employed in alkaline medium, the main species are expected to be $\mathrm{H}_{3} \mathrm{IO}_{6}^{2-}$ and $\mathrm{H}_{2} \mathrm{IO}_{6}^{3-}$. At higher concentrations, periodate also tends to dimerize. ${ }^{17} \mathrm{How}-$ ever, formation of this species is negligible under conditions employed for kinetic study. Hence, at the $\mathrm{pH}$ employed in this study, the soluble copper(III) periodate complex exists as diperiodatocuprate (III), $\left[\mathrm{Cu}\left(\mathrm{H}_{3} \mathrm{IO}_{6}\right)\left(\mathrm{H}_{2} \mathrm{IO}_{6}\right)\right]^{2-}$, also supported by earlier work. ${ }^{2}$

\subsection{Mechanism}

Based on the experimental results, a mechanism is proposed for which all the observed orders in each constituent such as [oxidant], [reductant], $\left[\mathrm{OH}^{-}\right]$, and $\left[\mathrm{IO}_{4}^{-}\right]$may be well-accommodated. Lister ${ }^{18}$ proposed three forms of copper (III) periodate in alkaline medium as diperiodatocuprate(III)(DPC), monoperiodatocuprate(III)(MPC) and tetrahydroxocuprate(III). The tetrahydroxocuprate(III) is ruled out, as its equilibrium constant is $8.0 \times 10^{-11}$ at $40^{\circ} \mathrm{C}$. Hence, in the present study, DPC and MPC are considered to be as active forms of copper (III) periodate complex. The result of increase in rate of reaction with increase in alkalinity (table 1) can be explained in terms of prevailing equilibrium of formation of $\left[\mathrm{Cu}\left(\mathrm{H}_{3} \mathrm{IO}_{6}\right)\left(\mathrm{H}_{2} \mathrm{IO}_{6}\right)\right]^{2-}$ from $\left.\left[\mathrm{Cu}\left(\mathrm{H}_{3} \mathrm{IO}_{6}\right)_{2}\right)\right]^{-}$as given below

$$
\begin{aligned}
& {\left[\mathrm{Cu}\left(\mathrm{H}_{3} \mathrm{IO}_{6}\right)_{2}\right]^{-}+\mathrm{OH}^{-}} \\
& =\stackrel{\mathrm{K}_{1} \longrightarrow}{=}\left[\mathrm{Cu}\left(\mathrm{H}_{2} \mathrm{IO}_{6}\right)\left(\mathrm{H}_{3} \mathrm{IO}_{6}\right)\right]^{2-}+\mathrm{H}_{2} \mathrm{O} .
\end{aligned}
$$

Also the decrease in the rate with increase in periodate concentration suggests that the displacement of a ligand periodate takes place to give a free periodate and monoperiodatocuprate(III) (MPC) species from $\left[\mathrm{Cu}\left(\mathrm{H}_{2} \mathrm{IO}_{6}\right)\left(\mathrm{H}_{3} \mathrm{IO}_{6}\right)\right]^{2-}$ as given in equation (6)

$$
\begin{aligned}
& {\left[\mathrm{Cu}\left(\mathrm{H}_{2} \mathrm{IO}_{6}\right)\left(\mathrm{H}_{3} \mathrm{IO}_{6}\right)\right]^{2-}+2 \mathrm{H}_{2} \mathrm{O}} \\
& =\stackrel{\mathrm{K}_{2}-}{=}\left[\mathrm{Cu}\left(\mathrm{H}_{2} \mathrm{IO}_{6}\right)\left(\mathrm{H}_{2} \mathrm{O}\right)_{2}\right]+\left[\mathrm{H}_{3} \mathrm{IO}_{6}\right]^{2-} .
\end{aligned}
$$

Such type of equilibria have been well-noticed in literature. ${ }^{19}$ It may be expected that a lower periodate complex such as monoperiodatocuprate(III) (MPC) is more important in the reaction than the DPC in view of the observed inverse fractional order in periodate. With the known equilibrium constants, ${ }^{19}$ the individual concentrations of $[\mathrm{DPC}]_{\mathrm{f}}, \mathrm{DPC}$ and MPC were calculated. It was found that MPC was in higher concentration and nearly paralleled the rate variation with different $\left[\mathrm{OH}^{-}\right]$. Furthermore, the spectra of $\mathrm{Cu}(\mathrm{III})$ periodate complex was dependent on $\left[\mathrm{OH}^{-}\right]$and the absorption becomes almost constant, indicating the predominance of one species, presumably $\left[\mathrm{Cu}\left(\mathrm{H}_{2} \mathrm{IO}_{6}\right)\left(\mathrm{H}_{2} \mathrm{O}\right)_{2}\right]$. Because of this and the fact that rate is a function of $\left[\mathrm{OH}^{-}\right]$(less then unit order), the main oxidation species is likely to be $\left[\mathrm{Cu}\left(\mathrm{H}_{2} \mathrm{IO}_{6}\right)\left(\mathrm{H}_{2} \mathrm{O}\right)_{2}\right]$ and its formation equilibrium (6) is important in the reaction.

The less than unit order in [L-leucine] presumably results from formation of a complex (C) between the MPC species and L-leucine prior to the formation of the products. $\mathrm{K}_{3}$ is the composite equilibrium constant comprising the equilibrium to bind active species, MPC to L-leucine species to form a complex (C). This complex $(\mathrm{C})$ undergoes decomposition in a slow step to give the free radical species of L-leucine, periodate, $\mathrm{CO}_{2}$ and $\mathrm{Cu}(\mathrm{II})$. This free radical species of $\mathrm{L}-$ leucine reacts with one mole of MPC species in a fast step to form corresponding aldehyde, $\mathrm{Cu}(\mathrm{II}), \mathrm{NH}_{3}$ and periodate. This aldehyde further reacts with two more mole of MPC in a fast step to form the final products i.e., 3-methyl butanoic acid, $\mathrm{Cu}$ (II) and periodate. So, the detailed mechanistic pathway for the oxidation of L-leucine by diperiodatocuprate (III) is presented in scheme 1.

Since scheme 1 is in accordance with the generally well-accepted principle of non-complementary oxidations taking place in sequence of one-electron steps, the reaction between the substrate and oxidant would afford a radical intermediate. A freeradical scavenging experiment revealed such a possibility. This type of radical intermediate has also been observed in earlier work. ${ }^{20}$ Spectroscopic evidence for the complex formation between oxidant and substrate was obtained from UV-Vis spectra of L-leucine 
$\left(3.0 \times 10^{-4} \mathrm{~mol} \mathrm{dm}^{-3}\right)$, DPC $\left(5.0 \times 10^{-5} \mathrm{~mol} \mathrm{dm}^{-3}\right)$, $\left[\mathrm{OH}^{-}\right]\left(0.05 \mathrm{~mol} \mathrm{dm}^{-3}\right)$ and mixture of both. A hypsochromic shift of about $5 \mathrm{~nm}$ from 306 to $301 \mathrm{~nm}$ in the spectra of DPC was observed. The Michaelis-Menten plot also proved the complex formation between DPC and L-leucine, which explains the less than unit order dependence on [L-leucine]. Such a complex between a substrate and an oxidant has been observed in other studies. ${ }^{21}$ The diamagnetic $\left(\mathrm{dsp}^{2}\right)$ square planar structure of $\mathrm{Cu}(\mathrm{III})$ periodate in the form of DPC, MPC and the paramagnetic $\left(\mathrm{sp}^{3}\right)$ complex of $\mathrm{Cu}$ (III) and L-leucine can be formulated as shown below.

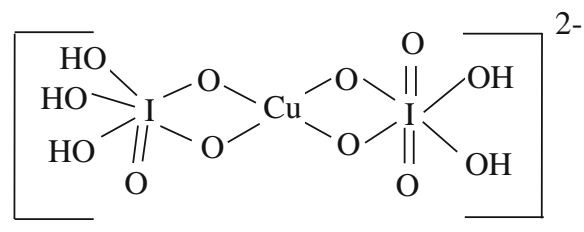

DPC<smiles>CCCCCCCCCCC</smiles>

Complex<smiles>CCO[Si]1(O)O[Si](O)(O)O[Si](O)(O)O1</smiles>

MPC

Scheme 1 leads to the rate law (7) (see appendix A)

$$
\text { Rate }=\frac{-\mathrm{d}[\mathrm{DPC}]}{\mathrm{dt}}=\frac{\mathrm{k} \mathrm{K}_{1} \mathrm{~K}_{2} \mathrm{~K}_{3}[\mathrm{DPC}][\mathrm{L}-\text { leucine }]\left[\mathrm{OH}^{-}\right]}{\left[\mathrm{H}_{3} \mathrm{IO}_{6}^{2-}\right]+\mathrm{K}_{1}\left[\mathrm{H}_{3} \mathrm{IO}_{6}^{2-}\right]\left[\mathrm{OH}^{-}\right]+\mathrm{K}_{1} \mathrm{~K}_{2}\left[\mathrm{OH}^{-}\right]+\mathrm{K}_{1} \mathrm{~K}_{2} \mathrm{~K}_{3}\left[\mathrm{OH}^{-}\right][\mathrm{L}-\text { leucine }]}
$$

this explains all the observed kinetic orders of different species.

$$
\mathrm{k}_{\mathrm{obs}}=\frac{\text { Rate }}{[\mathrm{DPC}]}=\frac{\mathrm{k} \mathrm{K}_{1} \mathrm{~K}_{2} \mathrm{~K}_{3}[\mathrm{~L}-\text { leucine }]\left[\mathrm{OH}^{-}\right]}{\left[\mathrm{H}_{3} \mathrm{IO}_{6}^{2-}\right]+\mathrm{K}_{1}\left[\mathrm{H}_{3} \mathrm{IO}_{6}^{2-}\right]\left[\mathrm{OH}^{-}\right]+\mathrm{K}_{1} \mathrm{~K}_{2}\left[\mathrm{OH}^{-}\right]+\mathrm{K}_{1} \mathrm{~K}_{2} \mathrm{~K}_{3}\left[\mathrm{OH}^{-}\right][\text {L-leucine }]}
$$

The rate law (8) can be rearranged into the following form, which is suitable for verification.

$$
\frac{1}{\mathrm{k}_{\mathrm{obs}}}=\frac{\left[\mathrm{H}_{3} \mathrm{IO}_{6}^{2-}\right]}{\mathrm{kK}_{1} \mathrm{~K}_{2} \mathrm{~K}_{3}[\mathrm{~L}-\text { leucine }]\left[\mathrm{OH}^{-}\right]}+\frac{1}{\mathrm{kK}_{2} \mathrm{~K}_{3}[\mathrm{~L}-\text { leucine }]}+\frac{1}{\mathrm{kK}_{3}[\mathrm{~L}-\text { leucine }]}+\frac{1}{\mathrm{k}}
$$

According to Eq. (9), other conditions being constant, plots of $1 / k_{\mathrm{obs}}$ versus $1 /\left[\mathrm{OH}^{-}\right](r \geq 0.9780$, $S \leq 0.029), 1 / k_{\text {obs }}$ versus $1 /$ [L-leucine] $(r \geq 0.9933$, $S \leq 0.016)$, and $1 / k_{\text {obs }}$ versus $\left[\mathrm{H}_{3} \mathrm{IO}_{6}^{2-}\right](r \geq 0.991$, $S \leq 0.011$ ) should be linear and are found to be so (figure 4). The slopes and intercepts of such plots lead to the values of $\mathrm{K}_{1}, \mathrm{~K}_{2}, \mathrm{~K}_{3}$, and $\mathrm{k}$ as (1.19 \pm $0.03) \mathrm{dm}^{3} \mathrm{~mol}^{-1},(4.25 \pm 0.30) \times 10^{-5} \mathrm{~mol} \mathrm{dm}^{-3}$, $(6.14 \pm 0.10) \times 10^{3} \mathrm{dm}^{3} \mathrm{~mol}^{-1}$, and $(3.70 \pm 0.40) \times$
$10^{-3} \mathrm{~s}^{-1}$, respectively at $298 \mathrm{~K}$. The value of $\mathrm{K}_{1}$ is in good agreement with earlier work. ${ }^{19}$ Using these $K_{1}$, $\mathrm{K}_{2}, \mathrm{~K}_{3}$, and $\mathrm{k}$ values, the rate constants under different experimental conditions were calculated by Eq. (8) and compared with experimental data. The results show a good agreement (table 1), which fortifies the scheme 1. Similarly $\mathrm{K}_{1}, \mathrm{~K}_{2}, \mathrm{~K}_{3}$, and $\mathrm{k}$ values were calculated at four different temperatures and are given in tables $3 \mathrm{a}$ and $3 \mathrm{~b}$. A vant Hoff's plot was made for variation 
of $\mathrm{K}_{1}$ with temperature $\left(\log \mathrm{K}_{1}\right.$ vs. $1 / T$ ( $r \geq 0.9811$, $S \leq 0.006)$ ) and the values of enthalpy of reaction $\Delta \mathrm{H}$, entropy of reaction $\Delta S$, and free energy of reaction $\Delta \mathrm{G}$
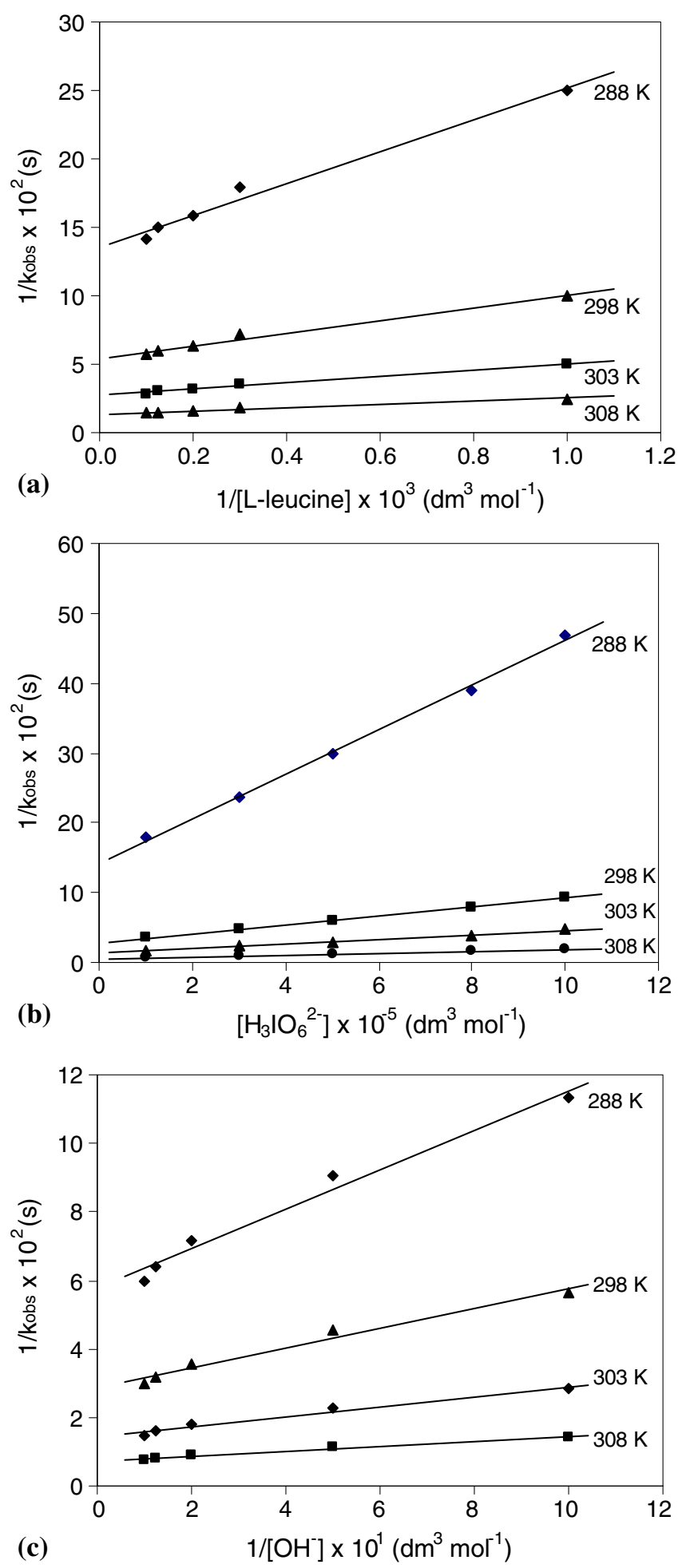

Figure 4. Verification of rate law (eqn. (8)) for the oxidation of L-leucine by diperiodatocuprate(III). (a) Plot of $1 / \mathrm{k}_{\mathrm{obs}}$ vs $1 /\left[\right.$ L-leucine], (b) Plot of $1 / \mathrm{k}_{\text {obs }}$ vs $1 /\left[\mathrm{H}_{3} \mathrm{IO}_{6}^{2-}\right]$ and (c) Plot of $1 / \mathrm{k}_{\text {obs }}$ vs $1 /\left[\mathrm{OH}^{-}\right]$at four different temperatures.
Table 3a. Effect of temperature on equilibrium constants of scheme 1 for the oxidation of L-leucine by diperiodatocuprate (III) in aqueous alkaline medium.

\begin{tabular}{lccc}
\hline $\begin{array}{l}\text { Temperature } \\
(\mathrm{K})\end{array}$ & $\begin{array}{c}\mathrm{K}_{1} \\
\left(\mathrm{~mol} \mathrm{dm}^{-3}\right)\end{array}$ & $\begin{array}{c}\mathrm{K}_{2} \times 10^{5} \\
\left(\mathrm{~mol} \mathrm{dm}^{-3}\right)\end{array}$ & $\begin{array}{c}\mathrm{K}_{3} \times 10^{-3} \\
\left(\mathrm{dm}^{3} \mathrm{~mol}^{-1}\right)\end{array}$ \\
\hline 288 & 0.68 & 6.21 & 4.68 \\
298 & 1.19 & 4.25 & 6.14 \\
303 & 2.43 & 3.01 & 8.44 \\
308 & 4.53 & 1.94 & 9.59 \\
\hline
\end{tabular}

Table 3b. Thermodynamic quantities with respect to $\mathrm{K}_{1}$, $\mathrm{K}_{2}$ and $\mathrm{K}_{3}$.

\begin{tabular}{lccc}
\hline $\begin{array}{l}\text { Thermodynamic } \\
\text { quantities }\end{array}$ & $\begin{array}{c}\text { Values } \\
\text { from } \mathrm{K}_{1}\end{array}$ & $\begin{array}{c}\text { Values } \\
\text { from K }\end{array}$ & $\begin{array}{c}\text { Values } \\
\text { from K }\end{array}$ \\
\hline$\Delta \mathrm{H}\left(\mathrm{k} \mathrm{J} \mathrm{mol}^{-1}\right)$ & $69 \pm 3$ & $-42 \pm 4$ & $27 \pm 3$ \\
$\Delta \mathrm{S}\left(\mathrm{J} \mathrm{K}^{-1} \mathrm{~mol}^{-1}\right)$ & $236 \pm 15$ & $-224 \pm 10$ & $165 \pm 10$ \\
$\Delta \mathrm{G}\left(\mathrm{k} \mathrm{J} \mathrm{mol}^{-1}\right)$ & $-1.4 \pm 0.1$ & $25.5 \pm 2.0$ & $-22.1 \pm 1.1$ \\
\hline
\end{tabular}

were calculated for the first equilibrium step (tables $3 \mathrm{a}$ and $3 b)$. A comparison of $\Delta \mathrm{H}$ value $\left(69 \mathrm{k} \mathrm{J} \mathrm{mol}^{-1}\right)$ from $\mathrm{K}_{1}$ with that of $\Delta \mathrm{H}^{\#}\left(72 \mathrm{k} \mathrm{J} \mathrm{mol}^{-1}\right)$ of rate limiting step supports that the first step of scheme 1 is fairly fast since it involves low activation energy with those obtained for the slow step of the reaction. ${ }^{22}$ In the same manner, $\mathrm{K}_{2}$ and $\mathrm{K}_{3}$ values were calculated at different temperatures and their corresponding values of the thermodynamic quantities are given in tables $3 a$ and $3 b$.

The negligible effect of ionic strength and dielectric constant of the medium on the rate qualitatively explains the reaction between neutral charged species, as seen in scheme 1 . The values of $\Delta H^{\#}$ and $\Delta S^{\#}$ were both favourable for electron transfer processes. The negative value of $\Delta S^{\#}$ indicates that the complex (C) is more ordered than the reactants. ${ }^{23}$ The value of $\Delta \mathrm{S}^{\#}$ within the range for radical reaction has been described ${ }^{24}$ to the nature of electron pairing and unpairing processes and to the loss of degrees of freedom formerly available to the reactants upon the formation of rigid transition state. The observed modest enthalpy of activation and a relatively low value of the entropy of activation as well as a higher rate constant of the slow step indicate that the oxidation presumably occurs via inner-sphere mechanism. This conclusion is supported by earlier observation. ${ }^{25}$

\section{Conclusions}

Among the various species of DPC in aqueous alkaline medium, $\left[\mathrm{Cu}\left(\mathrm{H}_{2} \mathrm{IO}_{6}\right)\left(\mathrm{H}_{2} \mathrm{O}\right)_{2}\right]$ is considered as 
active species for the title reaction. The results indicated that in carrying out this reaction, the role of $\mathrm{pH}$ in the reaction medium is crucial. Rate constant of slow step and other equilibrium constants involved in the mechanism are evaluated. The overall mechanistic sequence described here is consistent with all the experimental evidences including the product, spectral, mechanistic and kinetic studies.

\section{Appendix A}

Derivation of rate law for the reaction

According to scheme 1

$$
\begin{aligned}
\text { Rate } & =\frac{-\mathrm{d}[\mathrm{DPC}]}{\mathrm{dt}}=\mathrm{k}[\mathrm{C}] \\
\text { Rate } & =\frac{\mathrm{k} \mathrm{K}_{1} \mathrm{~K}_{2} \mathrm{~K}_{3}[\mathrm{~L} \text {-leucine }][\mathrm{DPC}]\left[\mathrm{OH}^{-}\right]}{\left[\mathrm{H}_{3} \mathrm{IO}_{6}^{2-}\right]} .
\end{aligned}
$$

Total concentration of DPC is given by

$$
\begin{aligned}
& {[\mathrm{DPC}]_{\mathrm{T}}=} {[\mathrm{DPC}]_{\mathrm{f}}+\left[\mathrm{Cu}\left(\mathrm{H}_{2} \mathrm{IO}_{6}\right)\left(\mathrm{H}_{3} \mathrm{IO}_{6}\right)\right]^{2-} } \\
&+\left[\mathrm{Cu}\left(\mathrm{H}_{2} \mathrm{IO}_{6}\right)\left(\mathrm{H}_{2} \mathrm{O}\right)_{2}\right]+\text { Complex } \\
& {[\mathrm{DPC}]_{\mathrm{T}}=[\mathrm{DPC}]_{\mathrm{f}}\left\{1+\mathrm{K}_{1}\left[\mathrm{OH}^{-}\right]+\frac{\mathrm{K}_{1} \mathrm{~K}_{2}\left[\mathrm{OH}^{-}\right]}{\left[\mathrm{H}_{3} \mathrm{IO}_{6}^{2-}\right]}\right.} \\
&\left.+\frac{\mathrm{K}_{1} \mathrm{~K}_{2} \mathrm{~K}_{3}\left[\mathrm{OH}^{-}\right][\text {L-leucine }]}{\left[\mathrm{H}_{3} \mathrm{IO}_{6}^{2-}\right]}\right\},
\end{aligned}
$$

where $\mathrm{T}$ and $\mathrm{f}$ refer to total and free concentrations. Therefore,

$$
[\mathrm{DPC}]_{\mathrm{f}}=\frac{\left[\mathrm{DPC}_{\mathrm{T}}\left[\mathrm{H}_{3} \mathrm{IO}_{6}^{2-}\right]\right.}{\left[\mathrm{H}_{3} \mathrm{IO}_{6}^{2-}\right]+\mathrm{K}_{1}\left[\mathrm{OH}^{-}\right]\left[\mathrm{H}_{3} \mathrm{IO}_{6}^{2-}\right]+\mathrm{K}_{1} \mathrm{~K}_{2}\left[\mathrm{OH}^{-}\right]+\mathrm{K}_{1} \mathrm{~K}_{2} \mathrm{~K}_{3}\left[\mathrm{OH}^{-}\right][\mathrm{L}-\text { leucine }]} .
$$

Similarly,

$$
[\text { L-leucine }]_{\mathrm{T}}=[\text { L-leucine }]_{\mathrm{f}}+[\text { Complex }]
$$

$[\text { L-leucine }]_{\mathrm{f}}$

$$
=\frac{[\mathrm{L}-\text { leucine }]_{\mathrm{T}}\left[\mathrm{H}_{3} \mathrm{IO}_{6}^{2-}\right]}{\left[\mathrm{H}_{3} \mathrm{IO}_{6}^{2-}\right]+\mathrm{K}_{1} \mathrm{~K}_{2} \mathrm{~K}_{3}\left[\mathrm{OH}^{-}\right]\left[\mathrm{Cu}\left(\mathrm{H}_{3} \mathrm{IO}_{6}\right)_{2}\right]^{-}} \text {. }
$$

In view of low concentration of DPC used, the term $\mathrm{K}_{1} \mathrm{~K}_{2} \mathrm{~K}_{3}\left[\mathrm{OH}^{-}\right]\left[\mathrm{Cu}\left(\mathrm{H}_{3} \mathrm{IO}_{6}\right)_{2}\right]^{-}$compared to $\left[\mathrm{H}_{3} \mathrm{IO}_{6}^{2-}\right]$ can be neglected. Hence,

$$
[\text { L-leucine }]_{\mathrm{f}}=[\text { L-leucine }]_{\mathrm{T}} \text {. }
$$

$$
\text { Similarly, } \quad\left[\mathrm{OH}^{-}\right]_{\mathrm{f}}=\left[\mathrm{OH}^{-}\right]_{\mathrm{T}}
$$

Substituting (II), (III), and (IV) in (I) and omitting the subscripts $\mathrm{T}$ and $\mathrm{f}$,

We get,

$$
\text { Rate }=\frac{-\mathrm{d}[\mathrm{DPC}]}{\mathrm{dt}}=\frac{\mathrm{k} \mathrm{K}_{1} \mathrm{~K}_{2} \mathrm{~K}_{3}[\mathrm{DPC}][\mathrm{L}-\text { leucine }]\left[\mathrm{OH}^{-}\right]}{\left[\mathrm{H}_{3} \mathrm{IO}_{6}^{2-}\right]+\mathrm{K}_{3}\left[\mathrm{H}_{3} \mathrm{IO}_{6}^{2-}\right]\left[\mathrm{OH}^{-}\right]+\mathrm{K}_{1} \mathrm{~K}_{2}\left[\mathrm{OH}^{-}\right]+\mathrm{K}_{1} \mathrm{~K}_{2} \mathrm{~K}_{3}\left[\mathrm{OH}^{-}\right][\mathrm{L}-\text { leucine }]}
$$

\section{References}

1. Lalo D and Mahanti M M 1990 J. Chem. Soc., Dalton Trans. 311

2. Reddy K B, Sethuram B and Navaneeth Rao T 1984 Indian J. Chem. 23A 593
3. Kumar A, Vaishal A and Ramamurthy P 2000 Int. J. Chem. Kinet. 32286

4. Shettar R S and Nandibewoor S T 2005 J. Mol. Cat. A: Chem. 234137

5. Ramreddy M G, Sethuram B and Navaneeth Rao T 1978 Indian J. Chem. 16A 313 
6. Karlin K D and Gultneh Y (eds.) 1997 Progress in inorganic chemistry, Vol. 35. Lippard, S. J. New York: Wiley; p 220

7. Kitajima N and Moro-ka Y 1994 Chem. Rev. 94737

8. Peisach J, Alsen P and Bloomberg W E 1996 The biochemistry of copper, New York: Academic Press; p 49

9. Sridevi N, Padmavathi J and Yusuff K K M 2001 Transition Met. Chem. 26315

10. Murthy C P, Sethuram B and Navaneeth Rao T 1981 Z. Phys. Chem. 262336

11. Jeffery G H, Bassett J, Mendham J and Denney R C (eds.) 1966 Vogel's textbook of quantitative chemical analysis, 5th ed., UK: ELBS, Longman, Essex; p 455

12. Panigrahi G P and Misro P K 1978 Indian J. Chem. 16A 201

13. Feigl F 1975 Spot tests on organic analysis. New York: Elsevier; p 212

14. Hiremath G C, Mulla R M and Nandibewoor S T 2005 J. Chem. Res. 197

15. Reddy K B, Sethuram B and Navaneeth Rao T 1987 Z. Phys. Chem. 268706
16. Kiran T S, Hiremath C V and Nandibewoor S T 2006 Appl. Cat. A: Gen. 30579

17. Sethuram B 2003 Some aspects of electron transfer reactions involving organic molecules, New Delhi: Allied Publishers; $\mathrm{p} 78$

18. Lister M W 1953 Can. J. Chem. 31638

19. Hegde R N, Shetti N P and Nandibewoor S T 2009 Polyhedron. 283499

20. Hosamani R R, Hedge R N and Nandibewoor S T 2010 Monatsh Chem. 1411069

21. Naik $P$ N, Kulkarni $S$ D, Chimatadar $S A$ and Nandibewoor S T 2008 Indian J. Chem. 47A 1666

22. Rangappa K S, Raghavendra M P, Mahadevappa D S and Channegouda D 1998 J. Org. Chem. 63531

23. Weissberger A 1974 Investigations of rates and mechanism of reactions (E S Lewis (ed.)) Techniques of chemistry. Vol. 4. New York: Wiley; p 421

24. Walling C 1957 Free radicals in solution. New York: Academic Press; p 38

25. Farokhi S and Nandibewoor S T 2003 Tetrahedron. 59 7595 